\title{
Archaeological Survey Investigations of Private Land within the boundaries of the proposed Lower Bois d'Arc Creek Reservoir Project, Fannin County, Texas
}

\author{
Timothy K. Perttula \\ Heritage Research Center, Stephen F. Austin State University \\ Mark Walters \\ Heritage Research Center, Stephen F. Austin State University \\ Rodney J. Nelson \\ Heritage Research Center, Stephen F. Austin State University \\ Gary W. Cheatwood
}

Follow this and additional works at: https://scholarworks.sfasu.edu/ita

Part of the American Material Culture Commons, Archaeological Anthropology Commons, Environmental Studies Commons, Other American Studies Commons, Other Arts and Humanities Commons, Other History of Art, Architecture, and Archaeology Commons, and the United States History Commons

Tell us how this article helped you.

This Article is brought to you for free and open access by the Center for Regional Heritage Research at SFA ScholarWorks. It has been accepted for inclusion in Index of Texas Archaeology: Open Access Gray Literature from the Lone Star State by an authorized editor of SFA ScholarWorks. For more information, please contact cdsscholarworks@sfasu.edu. 
Archaeological Survey Investigations of Private Land within the boundaries of the proposed Lower Bois d'Arc Creek Reservoir Project, Fannin County, Texas

\section{Creative Commons License}

\section{(c) (i) (8)}

This work is licensed under a Creative Commons Attribution-NonCommercial 4.0 International License 


\title{
Archaeological Survey Investigations of Private Land within the boundaries of the proposed Lower Bois d'Arc Creek Reservoir Project, Fannin County, Texas
}

\author{
Timothy K. Perttula, Mark Walters, Rodney J. Nelson, and Gary W. Cheatwood
}

\section{Introduction}

At the request of a private landowner that has property within the boundaries of the proposed Lower Bois d'Arc Creek Reservoir in Fannin County, we completed volunteer archaeological survey investigations on a portion of this tract of private land on July 18, 2015. The proposed Lower Bois d'Arc Creek Reservoir is to be more than 16,500 acres in size; the project sponsor is the North Texas Municipal Water District, and the Tulsa District of the U.S. Army Corps of Engineers is currently reviewing the project sponsor's application for a Department of the Army permit under Section 404 of the Clean Water Act to construct the reservoir and associated facilities (U. S. Army Corps of Engineers, Tulsa District 2015).

Although the project area associated with the proposed reservoir is more than 17,000 acres, only 5,000 acres of the proposed project have received an archaeological survey (Davis et al. 2014). Based on consultation between the project sponsor, the Texas Historical Commission, and the Tulsa District, the remainder of the project area will apparently not receive archaeological survey investigations. The private lands we have investigated along Bois d'Arc Creek in the proposed reservoir area have not been examined previously by a professional archaeological survey team; these lands will be inundated by the flood pool of the reservoir as currently proposed. The landowner had contacted the Tulsa District in 2008 to inform them that there were archaeological sites on the property, but the Tulsa District has yet to follow up on that information.

\section{Setting}

The private land we examined is on an alluvial terrace landform (490-500 ft. amsl) about 10-20 feet above the floodplain of Bois d'Arc Creek; an old channel of the creek flows north-south just east of the base of the alluvial terrace (Figure 1). These lands are located east of the southern part of Survey Area Q examined by Davis et al. (2014:Figure 44).

Currently, the private land is in pasture, with a few hardwood trees along the edges of the landform, with almost no surface visibility (Figure 2). Because of the limited surface visibility in the thick pasture grasses, the archaeological survey investigations were conducted through the excavation and screening (through 1/4-inch screen mesh) of $35 \mathrm{~cm}$ diameter shovel tests placed in likely site areas across several parts of the landform. The findings from the shovel testing have been supplemented by the documentation of prehistoric artifact collections from the newly recorded sites obtained by Mr. John Loschke, a local Fannin County resident.

\section{Archaeological Survey Investigations}

During our archaeological survey investigations, we documented three prehistoric archaeological sites on private land, either through systematic shovel testing or from surface observations: the North Ridge site, the South Pasture site, and the JL Site. The locations of shovel tests were plotted using UTMs obtained from hand-held Garmin GPS units. A fourth site (SH site), located not far to the south of the South Pasture site on 


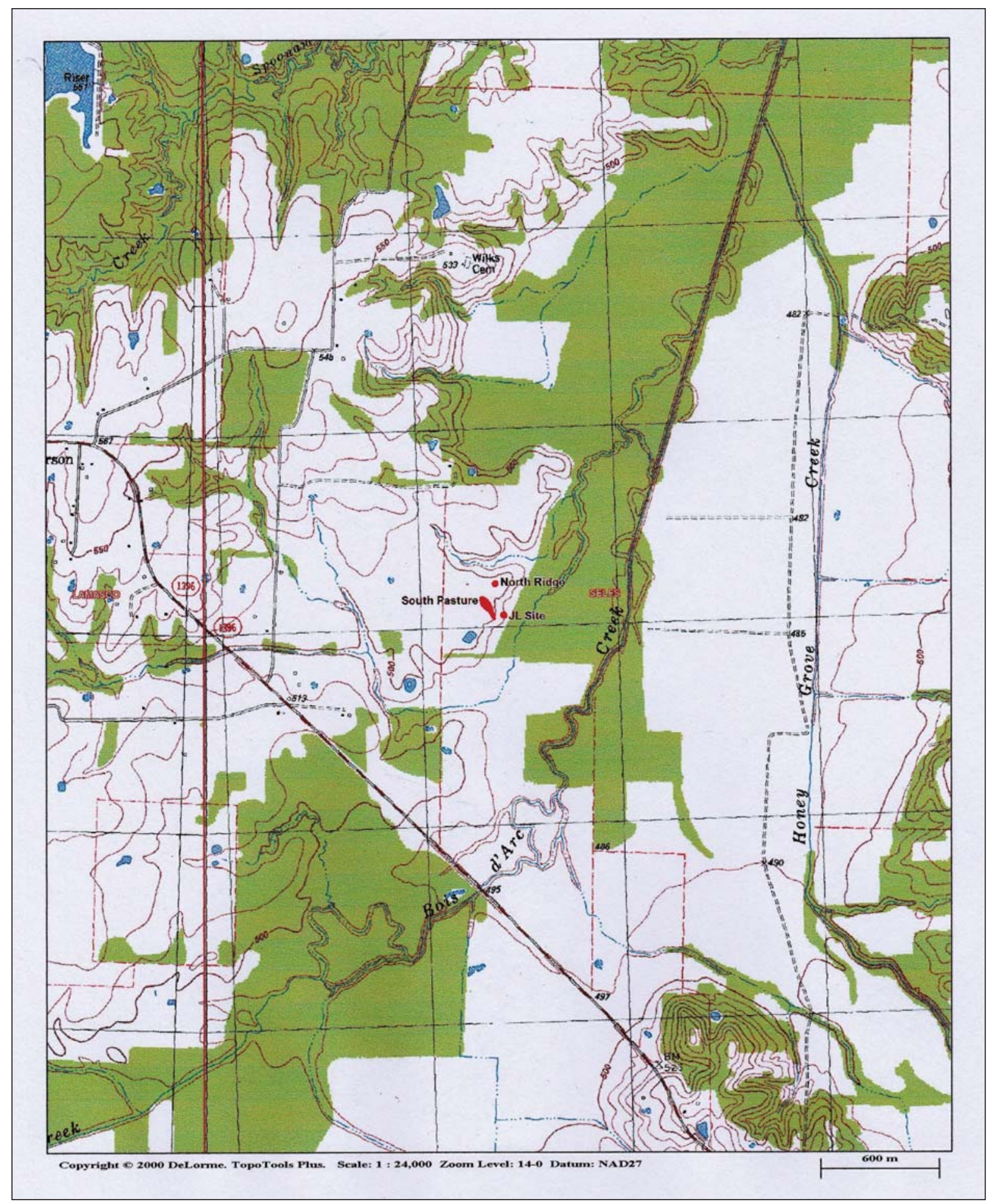

Figure 1. Location of newly discovered archaeological sites on private lands within the boundaries of the Lower Bois d'Arc Creek Reservoir in Fannin County, Texas, Selfs 7.5' USGS topographic quadrangle. 


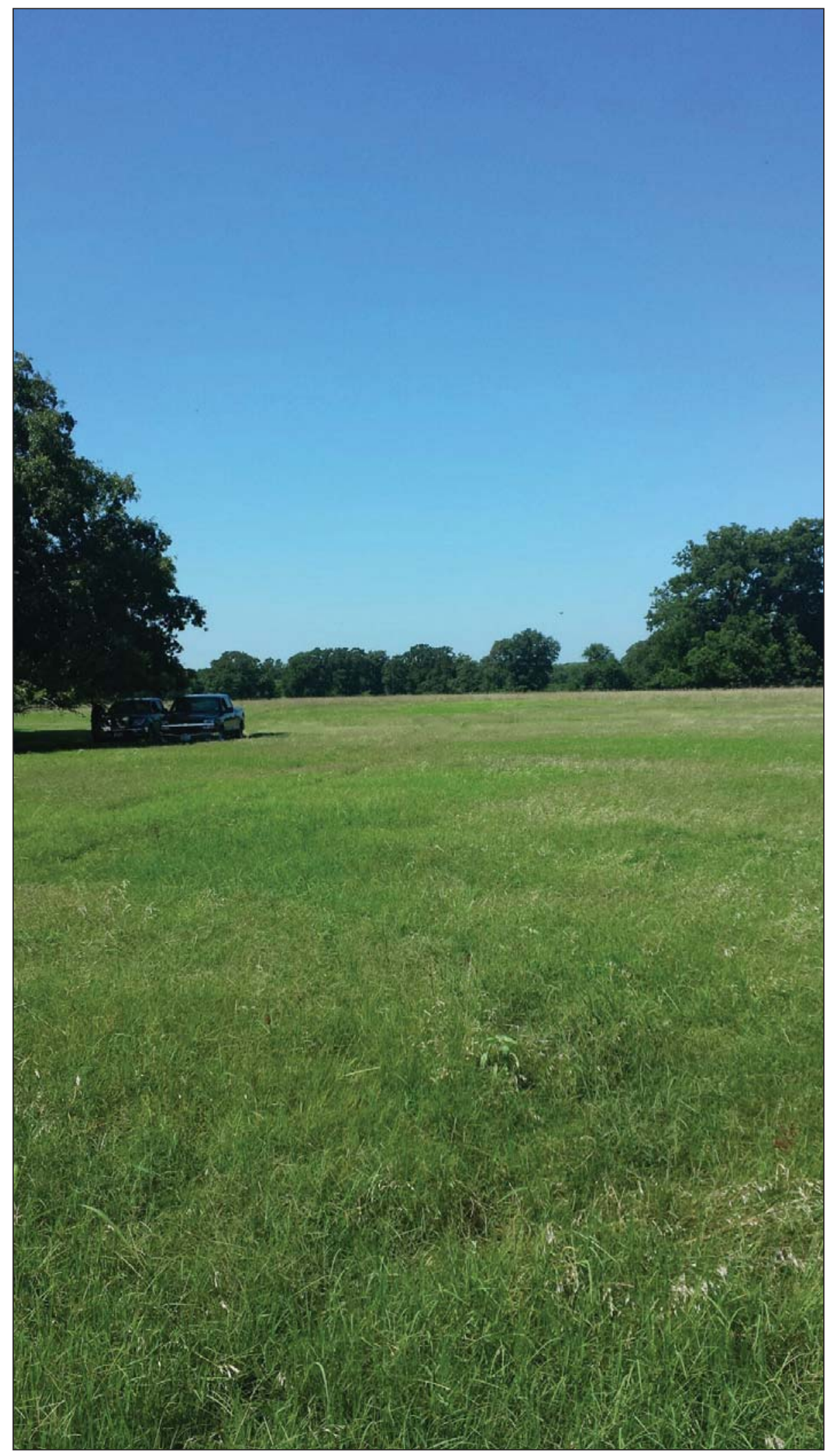

Figure 2. Looking southwest at the South Pasture site from the North Ridge site. 
the same alluvial terrace has been documented to date only through the examination of a private collection of artifacts from the site. It is likely, based on landforms on this tract of land, that there are at least 5-6 other prehistoric sites that remain to be documented within the boundaries of the proposed reservoir.

\section{North Ridge Site (41FN178)}

We excavated three shovel tests (A-C) on the crest of an alluvial terrace landform at the North Ridge site (Figure 3); all three shovel tests contain prehistoric artifacts. We estimate that the site likely covers at least 1-2 acres, but additional shovel tests would be needed to establish its extent on the landform.

The archaeological deposits at the North Ridge site are in a brown sandy loam A-horizon that ranges from 19-24 cm in thickness that overlies an orange clay B-Horizon:

ST A: 0-20 cm, brown sandy loam; $20+\mathrm{cm}$, orange sandy clay;

ST B: 0-24 cm, brown sandy loam; $24 \mathrm{~cm}+$, orange clay; and

ST C: 0-19 cm, brown sandy loam; $19 \mathrm{~cm}+$, orange clay.

Artifacts recovered in the shovel testing at the North Ridge site include lithic debris, one ceramic sherd, charred nutshell fragments (from ST B), and four pieces of fire- cracked rock. The highest densities of artifacts were recovered in ST A $(n=10)$ and ST B $(n=11)$; two pieces of lithic debris were recovered in ST C. The mean density of recovered artifacts from the archaeological deposits at the North Ridge site is 7.7 artifacts per positive shovel test, or ca. 61.6 artifacts per square meter of archaeological deposits.

A number of prehistoric artifacts from at least three components have been collected from the North Ridge site by Mr. John Loschke. This includes 25 dart points, two chipped stone drills, a ground stone tool, two celts, two arrow points from an ancestral Caddo occupation, a large chipped stone biface, and an ancestral Caddo tool punctated sherd (Figure 4) from a grog-tempered vessel; similar utility wares have been documented in a ca. A.D. 1100-1300 ceramic assemblage at the T. M. Sanders site on the Red River at the mouth of Bois d'Arc Creek (Perttula et al. 2015). The identified dart points include two Gary points from a Woodland period component and a Late Archaic style straight-stemmed dart point.

\section{South Pasture Site (41FN177)}

A total of 18 shovel tests were excavated at the South Pasture site, and 12 of them (ST 1, 3-5, 7-9, B-1, B-2, B-4, B-8, and B-9) contain prehistoric archaeological deposits (see Figure 3) in sandy loam to loam A-horizon sediments that range from 14-40 cm in thickness from the surface. These sediments overlie a B-horizon clay or sandy clay. The site covers an estimated 8,000 square meters (ca. 2 acres), but may well prove to be larger if and when additional shovel tests can be excavated at the site.

ST 1: 0-21 cm, light brown sandy loam; 21-23 cm+, orange sandy clay;

ST 2: 0-19 cm, brown sandy loam; 19-21 cm+, orange sandy clay;

ST 3: 0-15 cm, brown sandy loam; $15-18 \mathrm{~cm}+$, orange sandy clay

ST 4: 0-20 cm, light brown loam; 20-22 cm+, orange clay;

ST 5: 0-15 cm, light brown sandy loam; $15-17 \mathrm{~cm}+$, orange clay;

ST 6: 0-10 cm, brown loam; 10-14 cm+, orange clay; 


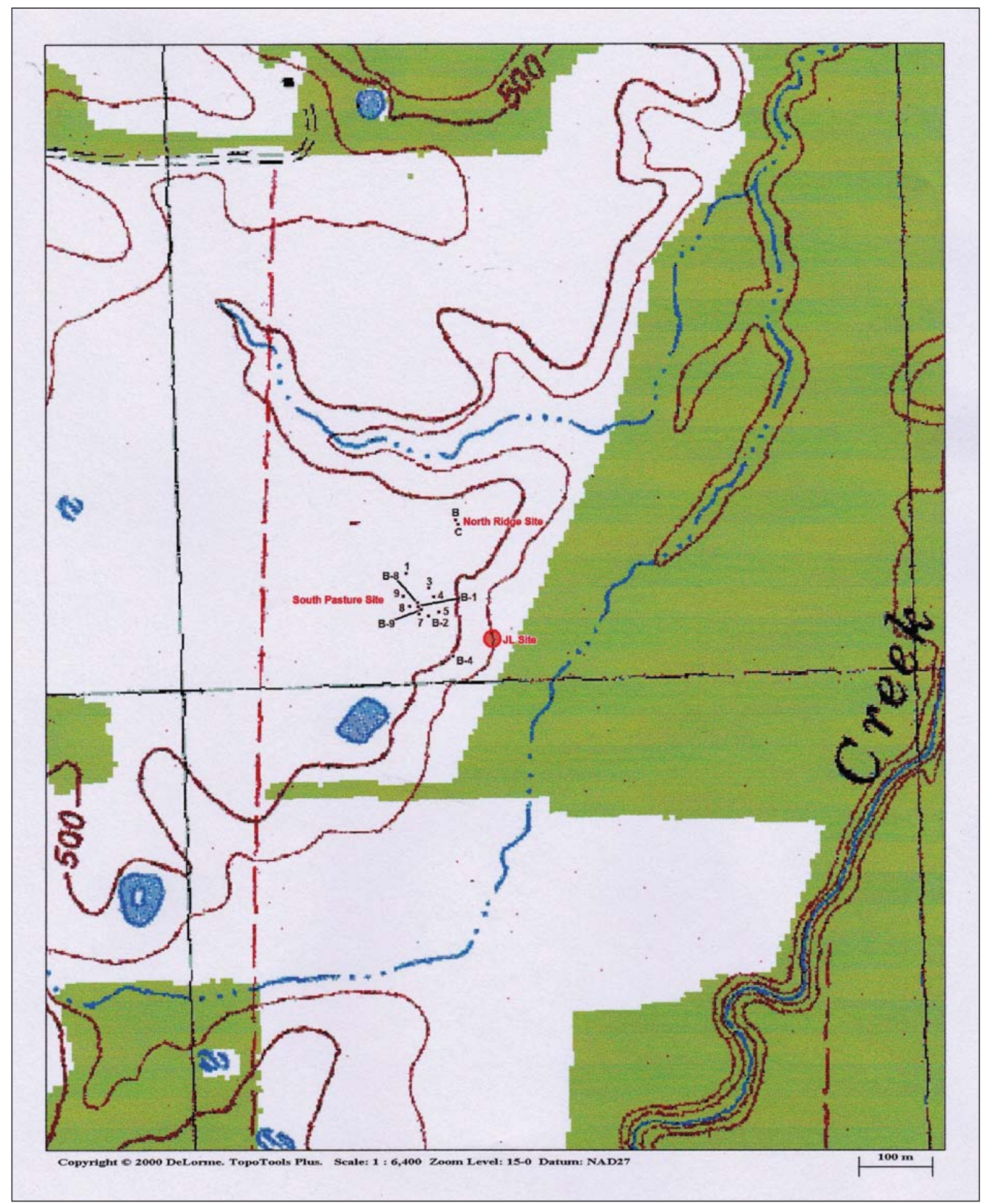

Figure 3. Locations of shovel tests with artifacts at the North Ridge and South Pasture sites. 


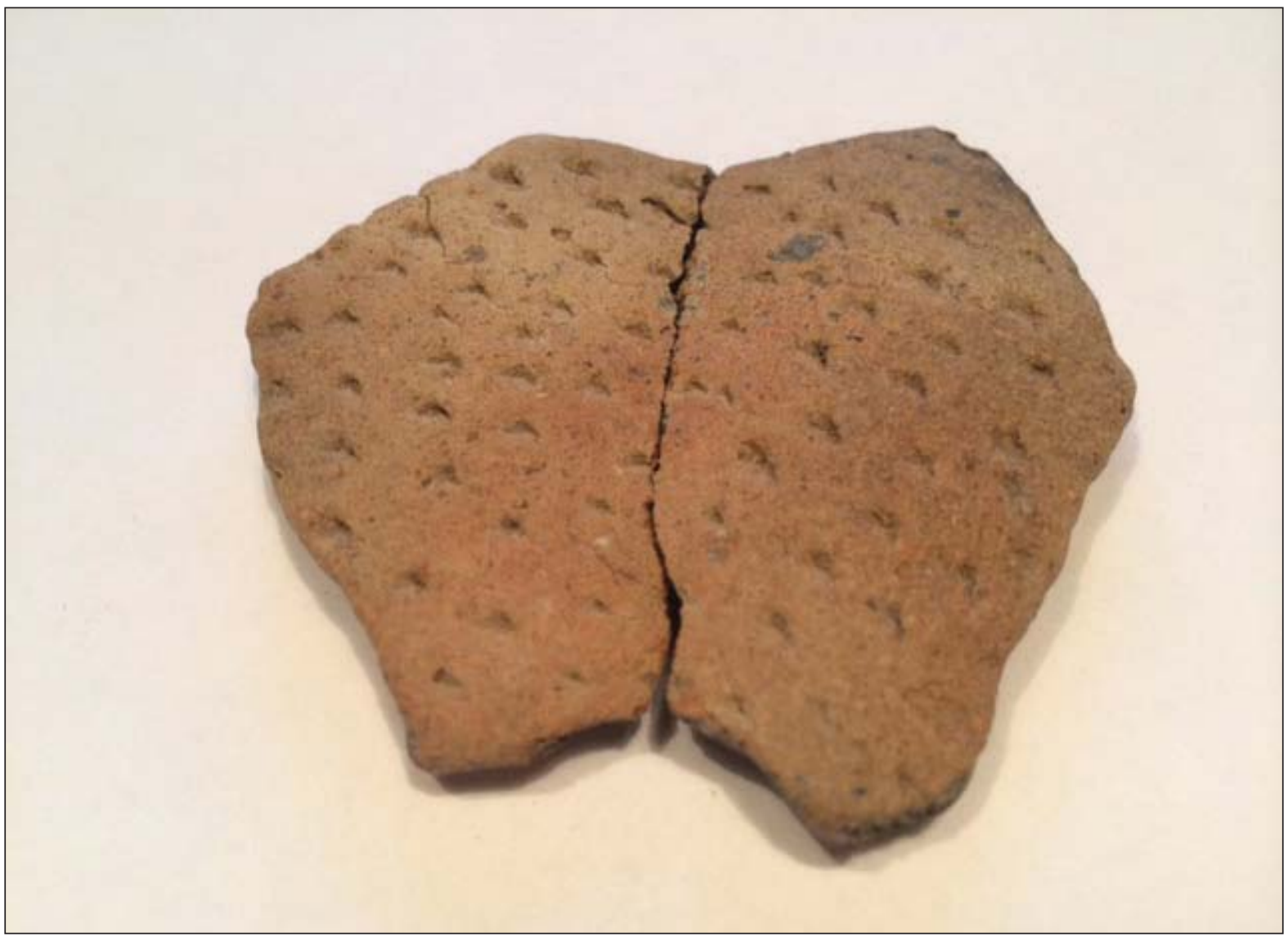

Figure 4. Tool punctated sherd from the North Ridge site.

ST 7: 0-14 cm, brown sandy loam; $14-16 \mathrm{~cm}+$, orange clay;

ST 8: 0-19 cm, brown sandy loam; $19-29 \mathrm{~cm}$, light brown sandy loam; $29-37 \mathrm{~cm}+$, orange clay

ST 9: 0-38 cm, light brown sandy loam; $38-40 \mathrm{~cm}+$, orange clay;

ST B-1: 0-40 cm, yellowish-brown sandy loam; 40-43 cm+, strong brown clay;

ST B-2: 0-18 cm, yellowish-brown sandy loam; $18-20 \mathrm{~cm}+$, strong brown clay;

ST B-3: 0-5 cm, yellowish-brown clayey loam; $5 \mathrm{~cm}+$, strong brown clay;

ST B-4: 0-20 cm, yellowish-brown sandy loam; 20-22 cm+, strong brown clay;

ST B-5: 0-12 cm, yellowish-brown sandy loam; $12-15 \mathrm{~cm}+$, strong brown clay;

ST B-6: 0-26 cm, yellowish-brown sandy loam; $26-28 \mathrm{~cm}+$, strong brown clay;

ST B-7: 0-25 cm, yellowish-brown sandy loam; $25-27 \mathrm{~cm}+$, strong brown clay;

ST B-8: 0-45 cm, yellowish-brown sandy loam; $45-48 \mathrm{~cm}+$, strong brown clay; and

ST B-9: 0-29 cm, yellowish-brown sandy loam; $29-31 \mathrm{~cm}+$, strong brown clay. 
The artifacts recovered in the shovel testing include lithic debris $(n=29)$, one ceramic sherd (in ST B-1), one arrow point fragment (in ST B-2), and one fire-cracked rock. The density of artifacts in the shovel tests ranges from 1-6 artifacts, with a mean density of 2.67 per positive shovel test; this is ca. 21.4 artifacts per square meter of archaeological deposits.

A wide variety of artifacts have been collected from the South Pasture site when it had been plowed in recent years. This includes 17 arrow points and arrow point fragments (Figure 5), one siliceous shale celt (Figure 6), 52 dart points, two scrapers, one Late Paleoindian Dalton point of a yellowish-gray chert, 66 biface fragments, and 22 ceramic sherds.

The ceramic sherds from the site are plain body and thick (15-20 mm+ in thickness) base sherds from bone-tempered $(\mathrm{n}=3)$ and grog-tempered $(\mathrm{n}=19)$ vessels. These sherds are likely from Williams Plain vessels, made in both Woodland and Early Caddo period times by ancestral Caddo populations living in the Red River basin (Ellis 2013; Perttula 2013).

The arrow points that have been documented from the site include Alba $(n=3)$, Catahoula $(n=1)$, and Colbert $(n=2)$, as well as one red chert arrow point with a very narrow parallel stem; these are Early Caddo period forms dating from ca. A.D. 900-1200. These arrow points are made from local raw materials, or materials available in Red River gravels: quartzite $(n=6)$, red jasper $(n=1)$, brown chert $(n=1)$, red chert $(n=3)$, gray chert $(n=2)$, light gray chert $(n=2)$, dark gray chert $(n=1)$, and novaculite $(n=1)$.

The identifiable dart points are Woodland period Gary $(\mathrm{n}=12)$ and Kent $(\mathrm{n}=1)$ types, and there is one possible Ensor dart point in the documented collection. Two other dart points with straight or expanding stems may be indicative of a Late Archaic component at the South Pasture site.

\section{JL Site (41FN176)}

No shovel tests were excavated at the JL site during our investigations. This site is located at the eastern end of the landform (ca. 490 feet amsl), elevated just above the Bois d'Arc Creek floodplain (see Figures 1 and 3). At this location, a ca. 10 square meter area of eroded alluvial sediments, a total of five pieces of nondiagnostic lithic debris were noted on the surface. We also documented from a private collection a single ancestral Caddo ceramic sherd previously collected from the surface of the site. This body sherd is from a grog-tempered utility ware vessel that has been decorated on the exterior vessel surface with at least three parallel rows of tool punctations.

\section{SH Site (41FN179)}

Time did not permit the full documentation of the SH site, another site on the investigated tract of private land within the boundaries of the proposed Lower Bois d'Arc Creek Reservoir. This site is ca. $300 \mathrm{~m}$ south of the South Pasture site (see Figure 1) on an alluvial terrace landform (500 ft. amsl).

Artifacts in a private collection from the SH site include 26 dart points and a chipped stone biface. The identified dart points in the collection include seven Gary and two Kent points, suggesting that the site has a Woodland period (ca. 500 B.C. to A.D. 800) component. 


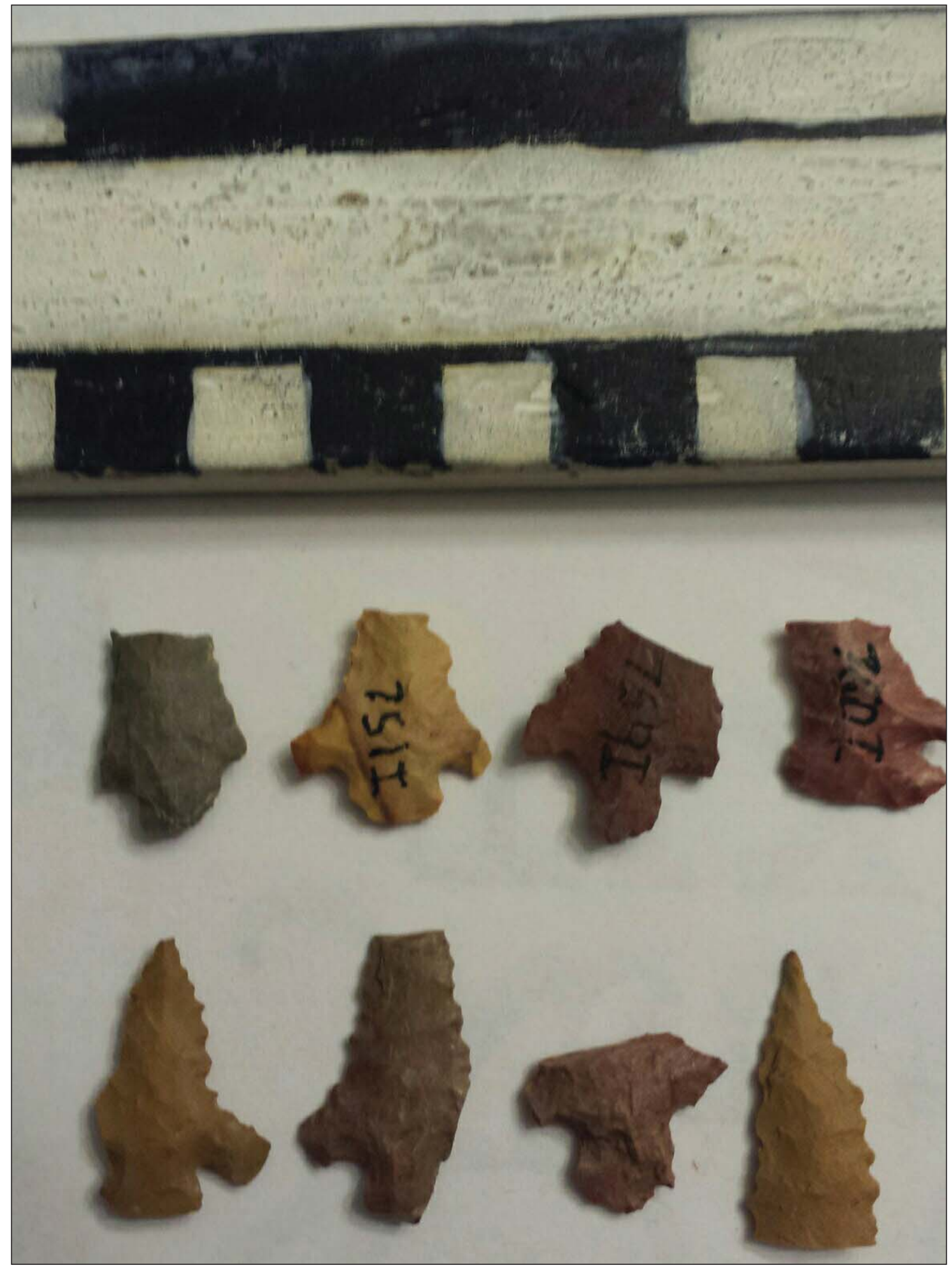

Figure 5. A sample of arrow points made of local raw materials from the South Pasture site. 


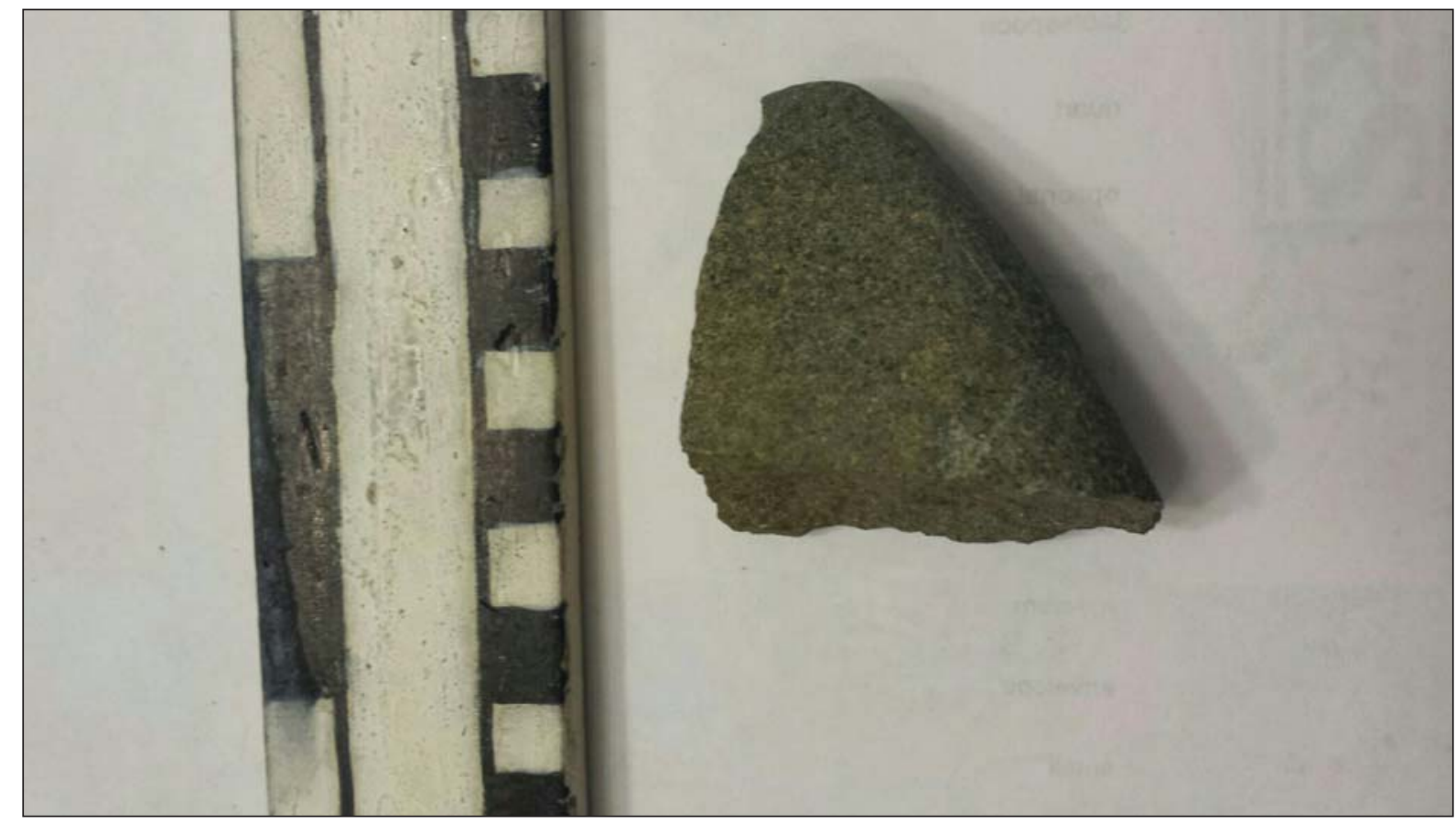

Figure 6. Siliceous shale celt fragment from the South Pasture site.

\section{Summary and Conclusions}

At the request of a private landowner with a tract of land within the boundaries of the proposed Lower Bois d'Arc Creek Reservoir in Fannin County that had not been surveyed by the North Texas Municipal Water District (Davis et al. 2014), we conducted a volunteer archaeological survey of one small part of the land to determine (a) if unrecorded archaeological sites were present there, and (b) gather information to help determine if such sites warranted further investigations to determine their eligibility for inclusion in the National Register of Historic Places and to determine if they qualified for State Archeological Landmark designation. During the course of our investigations on July 18, 2015, we located and have documented four different prehistoric archaeological sites on this private land tract. Shovel tests were completed at two of the sites (North Ridge and South Pasture sites), and this work demonstrated that there are intact archaeological deposits at both sites, a surface collection was completed at a third site (JL site), and a fourth site (SH site) was documented through an examination of artifacts held in a private collection. We also examined and documented large artifact collections from the other three sites as part of our work.

These various archaeological investigations indicate that the four sites were occupied from as early as the Late Paleoindian period (ca. 10,500-10,000 years B.P.) to the Middle Caddo period (ca. A.D. 11001300). The majority of the dart points from three of the sites are contracting stem Gary points with relatively narrow stem widths, suggesting that they were made and used in the Woodland period (cf. Schambach 1982). The plain grog- and bone-tempered sherds from the South Pasture site (41FN177) are from Williams Plain vessels, suggesting use of the site during both Woodland and early Caddo periods. The few decorated (i.e., tool punctated) sherds from the North Ridge (41FN178) and JL (41FN176) sites are from ancestral Caddo occupations, as are most of the arrow point forms recovered from the South Pasture site.

Because these four newly recorded sites - and likely others that have yet to be recorded on this private land tract - will be inundated by the waters of the proposed Lower Bois d'Arc Creek Reservoir and will be adversely effected by those waters, we recommend to the project sponsor, the Tulsa District of the U.S. Army Corps of Engineers, and the Texas Historical Commission that they receive further archaeological investigations to assess their research significance. These investigations should take place prior to any activities 
by the project sponsor that would damage the archaeological sites, and such investigations should include additional shovel tests as well as controlled excavations of sufficient intensity to determine the archaeological content and potential for preserved cultural features of each of the four sites. Additional archaeological survey investigations should be completed on this private land tract to identify other sites that have not yet been documented by the project sponsor.

Finally, because only ca. 30 percent of the proposed reservoir flood pool has been surveyed to date by the project sponsor (see Davis et al. 2014), and that 30 percent appears to be all that will be surveyed at the behest of the Tulsa District of the U.S. Army Corps of Engineers and the Texas Historical Commission, it is virtually a certainty that there are many undocumented and unrecorded archaeological sites in the project's area of potential effects that remain to be identified and evaluated. To insure the proper identification of all the sites that will be effected by the development of the reservoir, it will be important for the project sponsor, the Tulsa District of the U.S. Army Corps of Engineers, and the Texas Historical Commission to develop a plan now of survey and site evaluation efforts to identify and address those many undocumented and unrecorded archaeological sites on project lands. Such an effort will insure that the archaeological investigations carried out on sites in the Lower Bois d'Arc Creek Reservoir lands are in compliance with Section 106 of the National Historic Preservation Act and the Antiquities Code of Texas.

\section{Acknowledgments}

We first want to thank Harold Witcher, Jr. and his wife Patti for the opportunity to conduct the archaeological survey investigations reported on herein, and for their assistance in the archaeological survey work. We also thank Mr. Jon Loschke for sharing information about the archaeological materials in his collections from the four sites discussed in this article.

\section{References Cited}

Davis, C. S., S. A. Skinner, and M. A. Hall

2014 Archaeological Survey of the Proposed Lower Bois d'Arc Creek Reservoir, Fannin County, Texas. Cultural Resources Report 2014-60. AR Consultants, Dallas.

Ellis, L. W.

2013 Woodland Ceramics in East Texas and a Case Study of Mill Creek Culture Ceramics. Bulletin of the Texas Archeological Society 84:137-180.

Perttula, T. K.

2013 Caddo Ceramics in East Texas. Bulletin of the Texas Archeological Society 84:181-212.

Perttula, T. K., B. Nelson, M. Walters, and R. Z. Selden, Jr.

2015 The Sanders Site (41LR2): A Middle to Historic Caddo Settlement and Mound Center on the Red River in Lamar County, Texas. Journal of Northeast Texas Archaeology 50:1-87.

Schambach, F. F.

1982 An Outline of Fourche Maline Culture in Southwest Arkansas. In Arkansas Archeology in Review, edited by N. L. Trubowitz and M. D. Jeter, pp. 132-197. Research Series No. 15. Arkansas Archeological Survey, Fayetteville.

U.S. Army Corps of Engineers, Tulsa District

2015 Lower Bois d'Arc Creek Reservoir, Fannin County, Texas, Section 404 Permit Application, Draft Environmental Impact Statement, Volume I-DEIS. U.S. Army Corps of Engineers, Tulsa District, Tulsa. 